\title{
Stimulation of CD5 Enhances Signal Transduction by the T Cell Antigen Receptor
}

John B. Imboden, * Carl H. June, ${ }^{\ddagger}$ Michael A. McCutcheon, ${ }^{\star}$ and Jeffrey A. Ledbetter

*Department of Medicine, University of California and San Francisco Veterans Administration Medical Center, San Francisco, California 94121; ${ }^{\ddagger}$ Immunobiology and Transplantation Department, Naval Medical Research Institute,

Bethesda, Maryland 20814; and ${ }^{\S}$ Oncogen Corporation, Seattle, Washington 98121

\section{Abstract}

After the addition of a CD3 monoclonal antibody to peripheral $T$ cells that have been previously stimulated with phytohemagglutinin, inositol phosphates are produced at a rapid rate for $2 \mathrm{~min}$ and at a much slower rate thereafter. Stimulation of CD5 allows CD3-mediated production of inositol phosphates to be sustained at a brisk rate for $>20 \mathrm{~min}$ and augments the initial CD3-mediated increase in inositol trisphosphate and release of intracellular $\mathrm{Ca}^{2+}$. Thus, perturbation of $\mathrm{CD5}$ by monoclonal antibody enhances the ability of the CD3-antigen receptor complex to couple to the inositol phospholipid pathway. This effect of CD5 is independent of any direct effect of the CD5 monoclonal antibody on the levels of inositol phosphates. (J. Clin. Invest. 1990. 85:130-134.) CD5 • inositol phosphates $\cdot T$ cell activation

\section{Introduction}

Antigen receptor (CD3/Ti)-induced hydrolysis of membrane inositol phospholipids, leading to an increase in the concentration of cytoplasmic free $\mathrm{Ca}^{2+}\left(\left[\mathrm{Ca}^{2+}\right]_{i}\right)$ and to the activation of protein kinase $\mathrm{C}$, appears to play a prominent role in initiating the cellular responses of $T$ cells to antigen $(1,2)$. Physiological activation of $\mathrm{CD} 3 / \mathrm{Ti}$ requires contact between a $\mathrm{T}$ cell and an antigen-primed accessory cell, a situation that may permit a variety of additional receptor-ligand interactions to occur and participate in the activation process (3). Indeed, studies using MAb have identified several cell-surface molecules that are distinct from CD3/Ti but that augment CD3/ Ti-induced activation (reviewed in reference 4). Under appropriate conditions, MAb to certain of these putative accessory molecules, such as CD2 and CD28, can activate $T$ cells in the absence of CD3/Ti MAb, demonstrating that these molecules can deliver primary activation signals $(5,6)$.

One accessory molecule, CD5 (T1, Leu 1), is a 67-kD glycoprotein that is expressed on the surface of almost all T lymphocytes as well as a subset of B lymphocytes (7). Unlike CD2 and CD28, perturbation of CD5 by MAb has not been observed to activate $T$ cells $(8,9)$. CD5 MAb, however, can augment CD3/Ti-mediated production of IL-2 and proliferation under conditions where perturbation of $\mathrm{CD} 3 / \mathrm{Ti}$ alone elicits submaximal responses. For example, highly purified peripheral T cells, which are not activated by CD3 MAb immobilized

Address correspondence to Dr. John Imboden, Immunology Section (111R), Veterans Administration Medical Center, 4150 Clement St., San Francisco, CA 94121.

Received for publication 26 October 1988 and in revised form 8 September 1989.

The Journal of Clinical Investigation, Inc.

Volume 85, January 1990, 130-134 to Sepharose beads, produce IL-2 and proliferate when stimulated by the combination of a CD5 MAb and the immobilized CD3 MAb (8). Moreover, CD5 MAb can potentiate CD3-induced proliferation of previously activated $T$ cells (9). The natural ligand for CD5 has not been identified. Interestingly, expression of CD5 has been recently shown to restore responsiveness to IL-1 upon CD5-loss mutants of the $T$ cell line Jurkat (10). CD5, however, is clearly distinct from the recently cloned receptor for IL-1 (11). Moreover, optimal concentrations of IL-1 and CD5 MAb have additive effects on T cell activation, suggesting that these two stimuli regulate distinct signaling pathways $(9,10)$.

The nature of the signal(s) delivered by CD5 MAb is not known. When crosslinked, CD5 MAb, as well as MAb to a number of other $\mathrm{T}$ cell molecules, can increase $\left[\mathrm{Ca}^{2+}\right]_{i}(12)$. CD5 MAb can also enhance CD3/Ti-mediated $\mathrm{Ca}^{2+}$ influx, an effect that does not require crosslinking $(12,13)$. CD5, therefore, may either independently regulate a $\mathrm{Ca}^{2+}$ influx mechanism or influence signaling by $\mathrm{CD} 3 / \mathrm{Ti}$. In this communication we present evidence to support the latter possibility. We observe that perturbation of CD5 on highly purified peripheral $\mathrm{T}$ cells, which in itself has no effect on the levels of inositol phosphates (InsPs), ${ }^{1}$ substantially augments CD3/Ti-mediated production of InsPs. Stimulation of CD5 by MAb, therefore, enhances the ability of $\mathrm{CD} 3 / \mathrm{Ti}$ to trigger the hydrolysis of inositol phospholipids.

\section{Methods}

MAb. MAb 38.1 (anti-CD3; murine IgM), G19-4 (anti-CD3; murine IgG1), 10.2 (anti-CD5; murine IgG2a), 9.4 (anti-CD45; murine IgG2a), and HIDE (anti-HLA class I; murine IgG2a) have been described $(8,9,14)$. These MAb were purified from ascites by protein $A$ chromatography (10.2, 9.4, and HIDE), salt precipitation and DEAE chromatography (G19-4), or HPLC (38.1) using a 3000 SW Spherogel TSK column (Altex, San Ramon, CA).

Cells. Human PBMC were obtained by either venipuncture or leukophoresis of laboratory personnel, followed by Ficoll-Hypaque density centrifugation. To obtain PHA-stimulated blasts, PBMC were partially depleted of adherent cells by a 30 -min incubation on plastic at $37^{\circ} \mathrm{C}$ and then incubated in RPMI 1640 medium supplemented with $10 \%$ fetal bovine serum and $1 \mu \mathrm{g} / \mathrm{ml}$ PHA at $37^{\circ} \mathrm{C}$ in $5 \% \mathrm{CO}_{2}$ in air. To obtain a population of highly purified $\mathrm{T}$ cells, $\mathrm{T}$ cells were isolated from PBMC by negative selection with magnetic bead immunoabsorption after the addition of saturating concentrations of MAb to CD11, CD16, CD14, CD20, and HLA DR as described (14). The cells so obtained for these experiments were $>98 \% \mathrm{CD3}^{+} \mathrm{CD5}^{+}$as assessed by flow cytometry and contained $<0.1 \%$ monocytes as determined by nonspecific esterase staining (data not shown).

Proliferation assay. PHA blasts were washed and then cultured in quadruplicate samples in flat-bottomed, 96-well microtiter plates at 5 $\times 10^{4}$ cells/well in RPMI 1640 containing $10 \%$ heat-inactivated fetal

1. Abbreviations used in this paper: InsP, inositol phosphate. 
bovine serum. Cell proliferation was measured after pulsing cells for the final $6 \mathrm{~h}$ of 3-, 4-, and 5-d cultures with $1 \mu \mathrm{Ci} /$ well of $\left[{ }^{3} \mathrm{H}\right]$ thymidine (6.7 Ci/mmol; New England Nuclear, Boston, MA) as described (9).

Measurements of $\left[{ }^{3} \mathrm{H}\right]$ InsPs. We found that unstimulated $\mathrm{T}$ cells incorporated $\left[{ }^{3} \mathrm{H}\right]$ inositol poorly unless incubated with $\left[{ }^{3} \mathrm{H}\right]$ inositol in inositol-free medium with $10 \%$ heat-inactivated fetal bovine serum that had been dialyzed against Hepes-buffered saline to remove free inositol. Prolonged ( $>24 \mathrm{~h}$ ) incubation in this inositol-free medium, however, adversely affected cellular viability (data not shown). To achieve sufficient labeling of inositol phospholipids while avoiding inositol depletion, adherent cell-depleted PBMC were resuspended at $1-2 \times 10^{6}$ cells $/ \mathrm{ml}$ in RPMI 1640 (containing $0.2 \mathrm{mM}$ inositol) with $10 \%$ heat-inactivated fetal bovine serum (complete medium) supplemented with $1 \mu \mathrm{g} / \mathrm{ml}$ PHA and 20-50 $\mu \mathrm{Ci} m y o-2\left[^{3} \mathrm{H}\right]$ inositol $(37$ $\mathrm{mBq} / \mathrm{ml}$; New England Nuclear). After incubation for $72 \mathrm{~h}$ at $37^{\circ} \mathrm{C}$ in $5 \% \mathrm{CO}_{2}$ in air, cells were washed three times and resuspended at 5 $\times 10^{6}$ cells $/ \mathrm{ml}$ in complete medium with $10 \mathrm{mM} \mathrm{LiCl}$. After a 20-min incubation at $37^{\circ} \mathrm{C}, \mathrm{MAb}$ were added as indicated. The final concentrations of 10.2, 9.4, and HIDE were $10 \mu \mathrm{g} / \mathrm{ml}$. 38.1 was added to 1 $\mu \mathrm{g} / \mathrm{ml}$, the optimal concentration for stimulating InsP production. At the indicated time points cells were lysed with ice-cold $10 \%$ TCA and the $\left[{ }^{3} \mathrm{H}\right] \mathrm{InsPs}$ were extracted, separated by anion exchange chromatography using Dowex 1-X8 100-200 mesh in formate form (Bio-Rad Laboratories, Richmond, CA), and quantified as described (14).

Measurement of $\left[\mathrm{Ca}^{2+}\right]_{i}$. $\left[\mathrm{Ca}^{2+}\right]_{\mathrm{i}}$ responses were measured in single cells using indo-1 (Molecular Probes, Eugene, OR) and a flow cytometer (model $50 \mathrm{HH} / 2150$; Ortho Diagnostic Systems Inc., Westwood, MA) as described (12).

\section{Results}

CD5 MAb have been reported to enhance CD3-mediated proliferation of both resting and previously activated $T$ cells $(8,9)$. Consistent with these earlier observations, the CD5 MAb 10.2 substantially augmented CD3-mediated incorporation of $\left[{ }^{3} \mathrm{H}\right]$ thymidine into adherent cell-depleted human PBMC that had been previously stimulated with PHA (Fig. 1).

To determine the effects of CD5 MAb on CD3/Ti-mediated production of InsPs, we initially studied PHA blasts and used an IgM MAb to CD3, 38.1, which was a more effective CD3 agonist in terms of InsP production than the IgG CD3 MAb tested (G19.4, 64.1.1, and OKT3; data not shown). The addition of 38.1 led to a substantial increase in total $\left[{ }^{3} \mathrm{H}\right]$ InsPs within $\left[{ }^{3} \mathrm{H}\right]$ inositol-labeled PHA blasts. In the presence of $\mathrm{LiCl}$

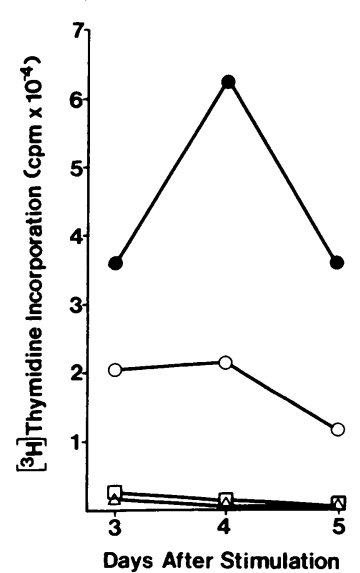

Figure 1. Perturbation of CD5 enhances CD3-mediated incorporation of $\left[{ }^{3} \mathrm{H}\right]$ thymidine into adherent celldepleted PBMC that had been previously stimulated with PHA. PHA blasts, prepared as described in Methods, were washed and then incubated for 3,4 , or $5 \mathrm{~d}$ in medium alone (口), or stimulated with soluble CD5 MAb alone ( $\triangle$ ), immobilized CD3 MAb alone (O), or the combination of soluble CD5 MAb and immobilized CD3 MAb (•). Anti-CD5 (10.2) was added to a final concentration of $1 \mu \mathrm{g} / \mathrm{ml}$; anti-CD3 (G19.4) was immobilized on microtiter wells at $20 \mu \mathrm{g} / \mathrm{ml}$. Cells were cultured in quadruplicate, and SE was $<18 \%$ of the mean. this response was characterized by a rapid increase for $2 \mathrm{~min}$, followed by a much slower accumulation of $\left[{ }^{3} \mathrm{H}\right] \mathrm{InsPs}$ (Fig. 2 ). Because $\mathrm{LiCl}$ inhibits the breakdown of Ins $\mathrm{P}_{1}$, this observation suggests that the production of InsPs proceeded at a brisk rate for the first 2 min after the addition of anti-CD3 and at a much slower rate thereafter. The simultaneous addition of anti-CD3 and anti-CD5 (10.2) did not affect the initial rise in $\left[{ }^{3} \mathrm{H}\right] \mathrm{InsPs}$, but after 2 min enhanced the rate of $\left[{ }^{3} \mathrm{H}\right]$ Ins $P$ accumulation approximately threefold (Fig. 2). The levels of $\left[{ }^{3} \mathrm{H}\right]$ InsPs after the simultaneous addition of anti-CD3 and anti-CD5 were significantly greater at 10 and $15 \mathrm{~min}(P<0.05$ and $<0.01$, respectively, by paired $t$ test) than those after the addition of the CD3 MAb alone. The CD5 MAb had a comparable enhancing effect on the $\left[{ }^{3} \mathrm{H}\right]$ InsP response to 64.1 .1 , an IgG2a MAb to CD3 (data not shown).

The addition of anti-CD5 alone to PHA blasts led to small but reproducible increases in total $\left[{ }^{3} \mathrm{H}\right]$ InsPs (Fig. 2). Small increases in $\left[{ }^{3} \mathrm{H}\right]$ InsPs also occurred after the addition of two control murine IgG2a MAb, 9.4 and HIDE, which recognize CD45 and HLA class I molecules, respectively (data not shown). Neither the anti-CD45 MAb nor the anti-HLA MAb, however, augmented the $\mathrm{CD} 3 / \mathrm{Ti}$-mediated $\left[{ }^{3} \mathrm{H}\right] \mathrm{InsP}$ response (data not shown; see Table I). Therefore, the ability of antiCD5 to enhance the production of InsPs by CD3/Ti appears to be specific. The changes in $\left[{ }^{3} \mathrm{H}\right] \mathrm{InsPs}$ induced by the CD5 $\mathrm{MAb}$ alone, on the other hand, may be largely nonspecific consequences of the addition of a murine IgG2a MAb reactive with cell-surface determinants in this cellular system.

The ability of CD5 MAb to promote CD3/Ti-mediated production of IL- 2 and proliferation does not require the presence of accessory cells (8). To determine whether the effects of anti-CD5 on the generation of InsPs are independent of non-T cells, we studied highly purified $\left(>98 \% \mathrm{CD}^{+}\right) \mathrm{T}$ cells. The addition of anti-CD5 alone to purified $\mathrm{T}$ cells caused no detectable change in $\left[{ }^{3} \mathrm{H}\right] \mathrm{InsPs}$, even in the presence of $\mathrm{LiCl}$ (Fig. 3). Although the use of purified $T$ cells eliminated the effect of the anti-CD5 alone on InsPs, the CD5 MAb retained its ability

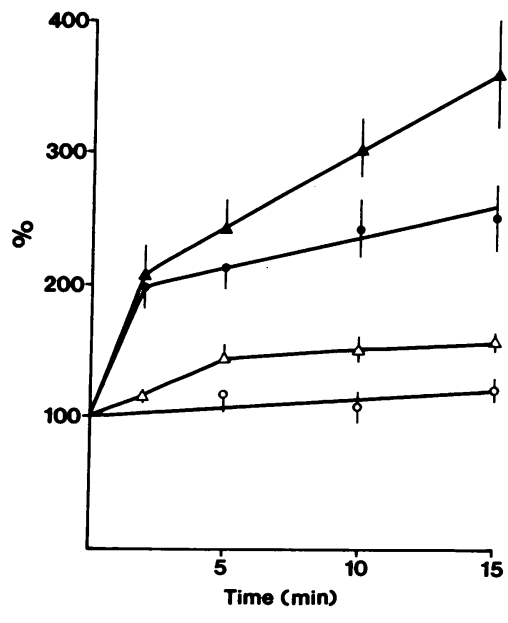

Figure 2. The levels of total $\left[{ }^{3} \mathrm{H}\right]$ InsPs over time within PBMC incubated in the absence of stimuli (O) or after the addition of a CD3 MAb (38.1) (•); a CD5 $\operatorname{MAb}(10.2)(\triangle)$; or antiCD3 plus anti-CD5 (४). Adherent cell-depleted PBMC were incubated for $72 \mathrm{~h}$ in complete medium containing PHA and $\left[{ }^{3} \mathrm{H}\right]$ inositol, washed, and then resuspended in medium with $10 \mathrm{mM} \mathrm{LiCl}$. After a 20-min incubation MAb were added at $t$

$=0$. Cells were lysed at the indicated time points and the extracted $\left[{ }^{3} \mathrm{H}\right]$ InsPs were resolved and quantified as described (14). Shown are the total $\left[{ }^{3} \mathrm{H}\right]$ InsPs (the sum of separately resolved $\left[{ }^{3} \mathrm{H}\right]$ Ins $\mathrm{P}_{1},\left[{ }^{3} \mathrm{H}\right]-$ Ins $P_{2}$, and $\left[{ }^{3} \mathrm{H}\right]$ Ins $\left.P_{3}\right)$ expressed as the percent of total $\left[{ }^{3} \mathrm{H}\right]$ InsPs in the unstimulated cells at $t=0$ (which was always $>450 \mathrm{cpm}$ ). Each point represents the mean \pm SEM of four to six separate experiments. 
Table I. The Effect of Anti-CD5 on CD3/Ti-mediated Production of InsPs within Resting Peripheral Blood T Cells

\begin{tabular}{|c|c|c|}
\hline \multirow[b]{2}{*}{ Pretreatment $^{\ddagger}$} & \multicolumn{2}{|c|}{ Total $\left[{ }^{3} \mathrm{H}\right] \mathrm{InsPs}{ }^{*}$} \\
\hline & Unstimulated & Anti-CD3 \\
\hline None & $1,885 \pm 77$ & $17,193 \pm 290$ \\
\hline Anti-CD5 (10.2) & $2,179 \pm 44$ & $20,936 \pm 583$ \\
\hline Anti-HLA class I (HIDE) & $2,669 \pm 80$ & $15,865 \pm 685$ \\
\hline
\end{tabular}

* Means and SE of triplicate cell samples. Each data point represents the total $\left[{ }^{3} \mathrm{H}\right] \mathrm{InsPs}$ in $10^{7}$ cells.

${ }^{\ddagger}$ Highly purified peripheral $\mathrm{T}$ cells were incubated in inositol-free medium supplemented with $20 \mu \mathrm{Ci} / \mathrm{ml}$ of $\left.{ }^{3} \mathrm{H}\right]$ inositol. After $18 \mathrm{~h}$ cells were washed, divided into aliquots of $10^{7}$ cells, and incubated for $20 \mathrm{~min}$ in medium containing $10 \mathrm{mM} \mathrm{LiCl}$ before the addition of MAb. After a 10-min pretreatment with either medium alone, 10.2, or HIDE, anti-CD3 (38.1) was added to selected samples. The reaction was terminated $20 \mathrm{~min}$ after the addition of anti-CD3.

to augment the InsP response to anti-CD3. As was observed with adherent cell-depleted PBMC, the combination of antiCD3 and anti-CD5, but not anti-CD3 alone, led to a continued generation of total $\left[{ }^{3} \mathrm{H}\right]$ InsPs, and to a sustained rise in $\left[{ }^{3} \mathrm{H}\right]-$ InsP ${ }_{1}$ for $>20$ min (Fig. 3, $A$ and $B$ ). Moreover, when antiCD5 was added several minutes before anti-CD3, there was an enhancement of the peak increase in total $\left[{ }^{3} \mathrm{H}\right] \mathrm{Ins}_{3}$ that occurred 2 min after the addition of the CD3 MAb (Fig. $3 C$ ).

The ability of anti-CD5 to enhance CD3/Ti-mediated production of InsPs did not require prior treatment with PHA and could be demonstrated using unstimulated, highly purified peripheral $\mathrm{T}$ cells that were labeled in inositol-free medium (Table I). The effect of anti-CD5 on resting T cells, however, was less than was observed with PHA-treated cells at the same time point. Thus, the enhancing effect of anti-CD5 may be more pronounced in preactivated cells than in resting cells, but we cannot exclude the possibility that the InsP response in the resting cells was distorted by prolonged inositol depletion. Of interest, pretreatment of freshly isolated, indo-1-loaded peripheral $\mathrm{T}$ cells with anti-CD5 led to a substantial increase in CD3/Ti-induced release of $\mathrm{Ca}^{2+}$ from intracellular stores, an event that is thought to be mediated by Ins-1,4,5- $P_{3}$. Enhanced intracellular $\mathrm{Ca}^{2+}$ mobilization was observed after the addition of either suboptimal (Fig. $4 \mathrm{~A}$ ) or optimal concentrations of CD3 MAb (Fig. 4 B).

\section{Discussion}

We show here that the addition of a CD5 MAb to peripheral T lymphocytes substantially augments the ability of CD3/Ti $\mathrm{MAb}$ to generate InsPs. After stimulation of $\mathrm{CD} 3 / \mathrm{Ti}$ alone on $T$ cells that had been previously activated with PHA, we found that the rate of InsP production slowed substantially after 2 min. This observation suggests one of two possibilities: $(a)$ the ability of $\mathrm{CD} 3 / \mathrm{Ti}$ to activate phospholipase $\mathrm{C}$ has been attenuated 2 min after stimulation, or (b) inositol phospholipid precursors have been depleted at this time point and are rate limiting for the CD3/Ti-activated phospholipase C. Perturbation of CD5, however, permits CD3/Ti-regulated generation of InsPs to be sustained at a brisk rate for at least $20 \mathrm{~min}$. Moreover, pretreatment of $\mathrm{T}$ cells with $\mathrm{CD} 5 \mathrm{MAb}$ enhances the peak CD3/Ti-mediated increase in InsP $_{3}$ and release of intracellular $\mathrm{Ca}^{2+}$, which occur within 2 min of the addition of $\mathrm{CD} 3 / \mathrm{Ti} \mathrm{MAb}$. These enhancing effects of the CD5 MAb are independent of any direct effect of the MAb itself on the levels of InsPs. Therefore, perturbation of CD5 by MAb appears either to promote the effective coupling of $\mathrm{CD} 3 / \mathrm{Ti}$ to phospholipase $\mathrm{C}$ or to increase the availability of inositol phospholipid precursors.

The ability of CD5 MAb to enhance the generation of InsPs by $\mathrm{CD} 3 / \mathrm{Ti}$ appears to be an example of a relatively unusual form of positive crosstalk between physically distinct receptors. A similar potentiation of receptor-mediated production of InsPs, however, has been described recently in fibroblasts after the addition of tyrosine kinase-activating growth factors $(15,16)$. For example, the addition of insulin to Swiss $3 T 3$ cells, which alone does not affect the levels of InsPs, augments bombesin-induced generation of InsPs (15). Moreover, fibroblast growth factor and epidermal growth factor, neither of which stimulates the production of InsPs, potentiate $\alpha$ thrombin-induced phosphoinositide breakdown in Chinese hamster fibroblasts (16). Despite the similarity between these observations and our studies of CD5, it is unlikely that a common, single mechanism accounts for potentiating effects of growth factors and CD5, because analysis of the predicted amino acid sequence of CD5 indicates that it is not a tyrosine kinase $(7,17)$. Huang et al., however, have pointed out that the sequence surrounding Tyr 429 of CD5 is similar to the autophosphorylation site of the members of the c-src family and have raised the possibility, as yet unproven, that CD5 may a substrate for a tyrosine kinase (17).

The functional consequences of the effects of CD5 MAb on

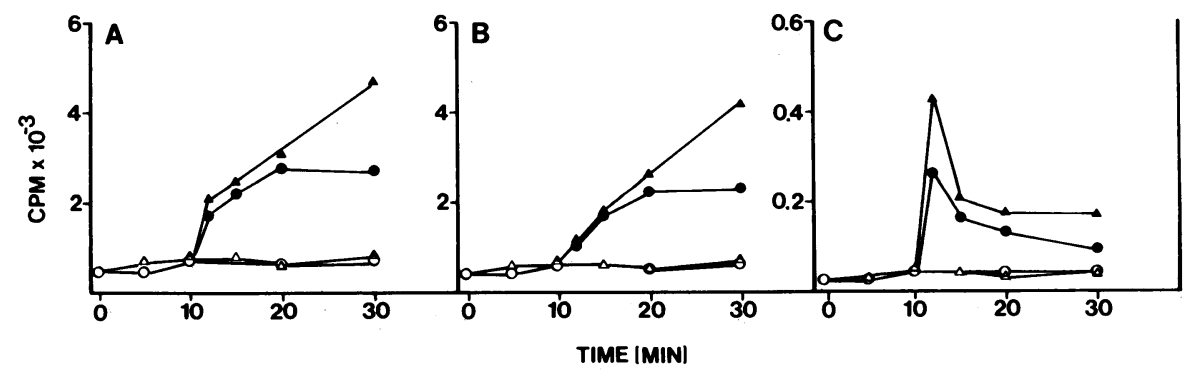
lysed at the indicated time points and the extracted $\left[{ }^{3} \mathrm{H}\right]$ InsPs were resolved and quantified as described (14).

Figure 3. Total $\left[{ }^{3} \mathrm{H}\right] \operatorname{InsPs}(A),\left[{ }^{3} \mathrm{H}\right] \operatorname{Ins} \mathrm{P}_{1}$ $(B)$, and $\left[{ }^{3} \mathrm{H}\right] \operatorname{Ins} \mathrm{P}_{3}(C)$ within highly purified peripheral blood $\mathrm{T}$ cells incubated in the absence of stimuli (o) or after the addition of CD5 MAb (10.2) alone ( $\triangle)$; CD3 $\operatorname{MAb}(38.1)$ alone (๑); or anti-CD5 and anti-CD3 ( $\triangle$ ). Purified (> 98\% $\mathrm{CD}^{+}$) T cells were incubated for $72 \mathrm{~h}$ in complete medium containing PHA and $\left[{ }^{3} \mathrm{H}\right]$ inositol, washed, and resuspended in medium with $10 \mathrm{mM} \mathrm{LiCl}$. After a 20-min incubation anti-CD5 was added to selected cell sam- 


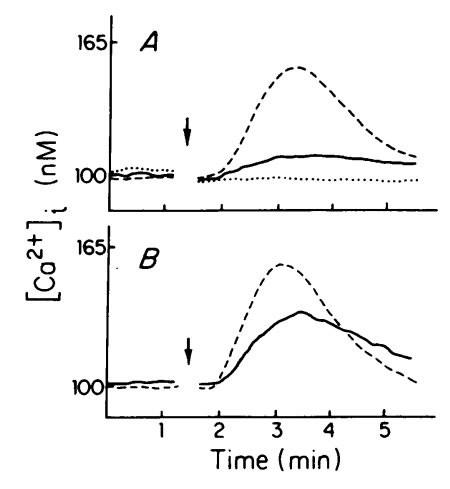

Figure 4. The effect of pretreatment with CD5 MAb on the ability of CD3 MAb to release $\mathrm{Ca}^{2+}$ from the intracellular stores of indo-1-loaded peripheral $\mathrm{T}$ cells. Freshly isolated PBMC were loaded with indo-1, resuspended in medium with $5 \mathrm{mM}$ EGTA to chelate extracellular $\mathrm{Ca}^{2+}$ and to prevent $\mathrm{Ca}^{2+}$ influx, and analyzed by flow cytometry as described (8). $A$, Cells were stimulated at $1.5 \mathrm{~min}$ with CD5 MAb (10.2) alone (dotted

line), with CD3 MAb (38.1) alone at a suboptimal concentration (0.1 $\mu \mathrm{g} / \mathrm{ml}$; solid line), or with anti-CD5 at -3 min followed by anti-CD3 $(0.1 \mu \mathrm{g} / \mathrm{ml})$ at $1.5 \mathrm{~min}$ (dashed line). B. Cells were stimulated with anti-CD3 at an optimal concentration $(1 \mu \mathrm{g} / \mathrm{ml})$ either alone (solid line) or after the addition of anti-CD5 at $-3 \mathrm{~min}$ (dashed line).

CD3/Ti-mediated production of InsPs are uncertain and are not addressed by this study. While these effects may explain the ability of CD5 MAb to potentiate CD3/Ti-mediated production of IL-2 and cell proliferation, it is certainly possible that CD5 also regulates additional activation pathways that are independent of the inositol phospholipid system and that play a critical role in $T$ cell activation. Three points, however, warrant comment with regard to the possible importance of the CD5-mediated effects on the generation of InsPs. First, sustained CD3/Ti-mediated signaling is required to initiate the production of IL-2 (reviewed in reference 3 ). Thus, the ability of CD5 MAb to permit CD3/Ti-mediated production of InsPs to continue at a brisk rate for an extended period of time is consistent with an effect on cellular activation. Second, in T lymphocytes Ins-1,4,5- $P_{3}$ appears to regulate the opening of $\mathrm{Ca}^{2+}$ channels in the plasma membrane, as well as the release of $\mathrm{Ca}^{2+}$ from intracellular stores $(18,19)$. An increase in the level of Ins-1,4,5- $P_{3}$, therefore, could explain the previously reported ability of CD5 MAb to augment CD3/Ti-mediated increases in $\left[\mathrm{Ca}^{2+}\right]_{\mathrm{i}}$ that require extracellular $\mathrm{Ca}^{2+}$ influx (12, 13). $\mathrm{Ca}^{2+}$ influx, which enables the increase in $\left[\mathrm{Ca}^{2+}\right]_{i}$ to be sustained, has been implicated in the activation of IL-2 gene expression $(3,19)$. In this study we were not able to achieve sufficient labeling of cells with $\left[{ }^{3} \mathrm{H}\right]$ inositol to measure $\left[{ }^{3} \mathrm{H}\right]$ Ins-1,4,5- $\mathrm{P}_{3}$ specifically by HPLC anion exchange chromatography, but did observe a clear effect of anti-CD5 on the initial CD3-induced increase in total Ins $P_{3}$. Finally, it should be remembered that diacylglycerol, an activator of the protein kinase $C$ family, is produced on an equimolar basis with InsPs during the hydrolysis of inositol phospholipids (20). Therefore, the substantial increase in the rate of production of InsPs (threefold in Fig. 2) is associated with a large increase in production of diacylglycerol and, accordingly, may be associated with substantial effects on the activation of protein kinase $\mathrm{C}$ isoforms.

In summary, we have shown that perturbation of CD5, which alone does not affect the levels of InsPs, potentiates the CD3/Ti-mediated generation of InsPs. This interaction between $\mathrm{CD} 5$ and $\mathrm{CD} 3 / \mathrm{Ti}$ indicates that $\mathrm{CD} 5$ either regulates the availability of inositol phospholipids or enhances the coupling of $\mathrm{CD} 3 / \mathrm{Ti}$ to phospholipase C. Further experiments will be needed to distinguish between these two mechanisms, and to determine whether this effect on CD3/Ti-mediated signaling contributes to the ability of CD5 to augment T cell activation.

\section{Acknowledgments}

This work was supported in part by National Institutes of Health grant RO1 AI-26644-01 (to Dr. Imboden), a Veterans Administration Merit Review award (to Dr. Imboden), and Naval Medical Research and Development Command 61152 MR0001.001 (to Dr. June). Dr. Imboden is a Pfizer Scholar.

\section{References}

1. Truneh, A., F. Albert, P. Golstein, and A. Schmitt-Verhulst. 1985. Early steps of lymphocyte activation bypassed by synergy between calcium ionophores and phorbol ester. Nature (Lond.). 313:318-321.

2. Imboden, J., C. Weyland, and J. Goronzy. 1987. Antigen recognition by a human $T$ cell clone leads to increases in inositol trisphosphate. J. Immunol. 138:1322-1324.

3. Schwartz, R. H. 1984. The role of gene products of the major histocompatibility complex in $\mathrm{T}$ cell activation and cellular interactions. In Fundamentals of Immunology. W. E. Paul, editor. Raven Press, New York. 379-438.

4. Weiss, A., and J. B. Imboden. 1987. Cell surface molecules and early events involved in human $\mathrm{T}$ lymphocyte activation. $A d v$. Immunol. 41:1-38.

5. Meuer, S. C., R. Hussey, M. Fabbi, D. Fox, O. Acuto, K. A. Fitzgerald, J. C. Hodgdon, J. P. Protentis, S. F. Schlossman, and E. L. Reinherz. 1984. An alternative pathway of T-cell activation: a functional role for the $50 \mathrm{kd} \mathrm{T11}$ sheep erythrocyte receptor protein. Cell. 36:897-906.

6. Hara, T., S. M. Fu, and J. A. Hansen. 1985. Human T cell activation. II. A new activation pathway used by a major T cell population via a disulfide-bonded dimer of a $\mathbf{4 4}$ kilodalton polypeptide (9.3 antigen). J. Exp. Med. 161:1513-1524.

7. Jones, N. H., M. L. Clabby, D. P. Dialynas, H.-J. S. Huang, L. A. Herzenberg, and J. L. Strominger. 1986. Isolation of complementary DNA clones encoding the human lymphocyte glycoprotein T1/Leu-1. Nature (Lond.). 323:346-349.

8. Ceuppens, J. L., and M. L. Baroja. 1986. Monoclonal antibodies to the $\mathrm{CD} 5$ antigen can provide the necessary second signal for activation of isolated resting $\mathrm{T}$ cells by solid-phase-bound OKT3. J. Immunol. 137:1816-1821.

9. Ledbetter, J. A., P. J. Martin, C. E. Spooner, D. Wofsy, T. T. Tsu, P. G. Beatty, and P. Gladstone. 1985. Antibodies to Tp67 and $\mathrm{Tp} 44$ augment and sustain proliferative responses of activated $\mathrm{T}$ cells. J. Immunol. 135:2331-2336.

10. Nishimura, Y., B. E. Bierer, and S. J. Burakoff. 1988. Expression of CD5 regulates responsiveness to IL-1. J. Immunol. 141:34383444.

11. Sims, J. E., C. J. March, D. Cosman, M. B. Widmer, H. R. MacDonald, C. J. McMahan, C. E. Grubin, J. Wignall, J. L. Jackson, S. M. Call, D. Friend, A. R. Alpert, S. Gillis, D. L. Urdal, and S. K. Dower. 1988. cDNA expression cloning of the IL-1 receptor, a member of the immunoglobulin superfamily. Science (Wash. DC). 241:585-589.

12. June, C. H., P. S. Rabinovitch, and J. A. Ledbetter. 198? . CD5 antibodies increase intracellular ionized calcium concentration in $\mathrm{T}$ cells. J. Immunol. 138:2782-2792.

13. Bierer, B. E., Y. Nishimura, S. J. Burakoff, and B. R. Smith. 1988. Phenotypic and functional characterization of human cytolytic T cells lacking expression of CD5. J. Clin. Invest. 81:1390-1397.

14. Ledbetter, J. A., C. H. June, P. S. Rabinovitch, A. Grossman, T. T. Tsu, and J. B. Imboden. 1988. Signal transduction through CD4 receptors: stimulatory vs. inhibitory activity is regulated by CD4 proximity to the CD3/T cell receptor. Eur. J. Immunol. 18:525-532. 
15. Heslop, J. P., D. M. Blakeley, K. D. Brown, R. F. Irvine, and M. J. Berridge. 1987. Effects of bombesin and insulin on inositol $(1,4,5)$ trisphosphate and inositol $(1,3,4)$ trisphosphate formation in swiss 3T3 cells. Cell. 47:703-707.

16. Paris, S., J.-C. Chambard, and J. Pouyssegur. 1988. Tyrosine kinase-activating growth factors potentiate thrombin- and $\mathrm{A} \mathrm{F}_{4}-\mathrm{in}$ duced phosphoinositide breakdown in hamster fibroblasts. J. Biol. Chem. 263:12893-12900.

17. Huang, H.-J., N. Jones, J. L. Strominger, and L. A. Herzenberg. 1987. Molecular cloning of $\mathrm{Ly}-1$, a membrane glycoprotein of mouse $T$ lymphocytes and a subset of B cells: molecular homology to its human counterpart Leu-1/T1 (CD5) Proc. Natl. Acad. Sci. USA. 84:204-208.

18. Kuno, M., and P. Gardner. 1987. Ion channels activated by inositol 1,4,5-trisphosphate in plasma membrane of human $\mathrm{T}$ lymphocytes. Nature (Lond.). 326:301-304.

19. Gardner, P., A. Alcover, M. Kuno, P. Moingeon, C. Weyland, J. Goronzy, and E. L. Reinherz. 1989. Triggering of T-lymphocytes via either T3-Ti or T11 surface structures opens a voltage-insensitive plasma membrane calcium-permeable channel: requirement for interleukin-2 gene function. J. Biol. Chem. 264:1068-1076.

20. Nishizuka, Y. 1986. Studies and perspectives of protein kinase C. Science (Wash. DC). 233:305-312. 